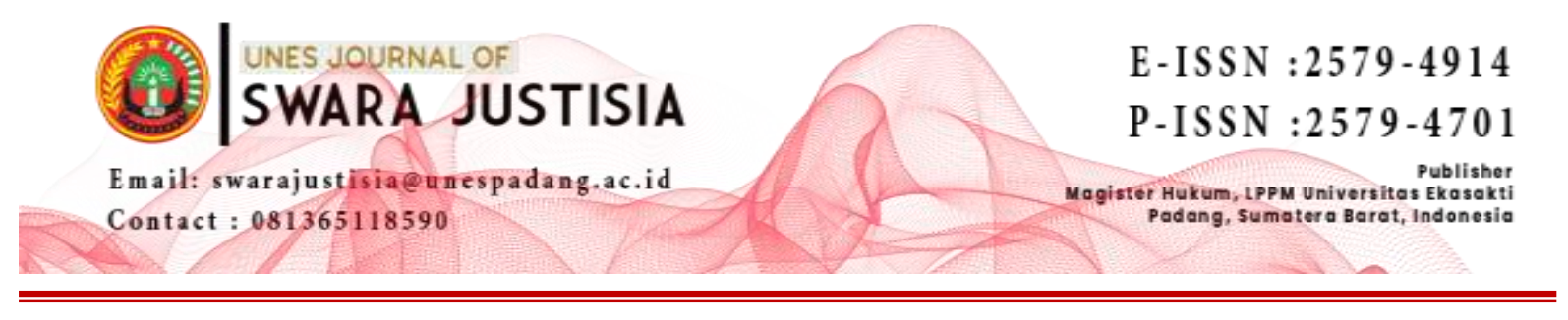

\title{
PERLINDUNGAN HUKUM BAGI APARATUR SIPIL NEGARA TERHADAP PELAYANAN PUBLIK PADA KANTOR WILAYAH ATR/BPN PROVINSI SUMATERA BARAT
}

\author{
Aridal Nova Daltim \\ Program Magister Ilmu Hukum,Universitas Ekasakti, Padang \\ Email: aridal1182@gmail.com
}

\begin{abstract}
Civil servants have an important role to play in carrying out development tasks and services to the community, this is stated in Law No. 5 of 2014 concerning ASN. In carrying out its duties, a Civil Servant (PNS) cannot be separated from the shortcomings and strengths that he does, one example of violations committed by the State Civil Apparatus of the Agam National Land Agency with alleged cases of corruption and misuse of certificates of shop houses (shophouses), kiosks in Lubuk Basung Old Market. The formulation of the problem in this research is, First, what is the legal protection for the State Civil Apparatus in providing services to the public at the ATR / BPN office of West Sumatra Province? Second, How is the effectiveness of the work of the State Civil Apparatus in public services at the West Sumatra Province ATR / BPN office?The specification of this research is descriptive analysis. The method used in this thesis research is to use a normative juridical approach which is supported by an empirical juridical approach, namely research in addition to looking at normative law also looks at the Legal Protection of State Civil Servants for public services in ATR / BPN West Sumatra Province. Based on the results of the research, it shows that (1) Legal protection for the State Civil Apparatus in providing services to the public at the ATR / BPN office of West Sumatra Province is in fact still not optimal because reforming the bureaucracy aimed at increasing the efficiency and effectiveness of the bureaucracy has not been carried out properly and obligations the government provides protection has not been realized and protection has not been issued. So that in case of negligence or mistakes made by ASN, the government only orders the Government Inspectorate to make efforts to resolve the problem. (2) The effectiveness of the work of the State Civil Apparatus in public services at the ATR / BPN office of West Sumatra Province is still not effective at this time. This is because there are several problems that have occurred and have not been resolved properly. For example, this happened when an ASN was sentenced because of an error in the HGB Management Rights service and the ASN did not get legal assistance, the government only made efforts to resolve the Building Use Rights case.
\end{abstract}

Keywords: legal protection, civil servant 


\begin{abstract}
ABSTRAK
Pegawai negeri sipil memiliki peran penting dalam melaksanakan tugas pembangunan dan pelayanan kepada masyarakat, hal ini tertuang dalam Undang-Undang Nomor 5 Tahun 2014 tentang ASN. Dalam menjalankan tugasnya seorang Pegawai Negeri Sipil (PNS) tidak lepas dari kekurangan dan kelebihan yang dilakukannya, salah satu contoh pelanggaran yang dilakukan oleh Aparatur Sipil Negara Badan Pertanahan Nasional Agam dengan dugaan kasus korupsi dan penyalahgunaan sertifikat hak milik. ruko (ruko), kios di Pasar Lama Lubuk Basung. Rumusan masalah dalam penelitian ini adalah, Pertama, bagaimana perlindungan hukum bagi Aparatur Sipil Negara dalam memberikan pelayanan kepada masyarakat di kantor ATR/BPN Provinsi Sumatera Barat? Kedua, Bagaimana efektivitas kerja Aparatur Sipil Negara dalam pelayanan publik di kantor ATR/BPN Provinsi Sumatera Barat? Spesifikasi penelitian ini adalah deskriptif analisis. Metode yang digunakan dalam penelitian skripsi ini adalah dengan menggunakan pendekatan yuridis normatif yang didukung dengan pendekatan yuridis empiris yaitu penelitian selain melihat hukum normatif juga melihat Perlindungan Hukum Pegawai Negeri Sipil Negara atas pelayanan publik di ATR/BPN Barat Provinsi Sumatera. Berdasarkan hasil penelitian menunjukkan bahwa (1) Perlindungan hukum bagi Aparatur Sipil Negara dalam memberikan pelayanan kepada masyarakat di kantor ATR/BPN Provinsi Sumatera Barat ternyata masih belum optimal karena pembenahan birokrasi bertujuan untuk meningkatkan efisiensi dan efektivitas birokrasi belum terlaksana dengan baik dan kewajiban pemerintah memberikan perlindungan belum terwujud dan perlindungan belum diterbitkan. Sehingga apabila terjadi kelalaian atau kesalahan yang dilakukan oleh ASN, pemerintah hanya memerintahkan Inspektorat Pemerintah untuk melakukan upaya penyelesaian masalah tersebut. (2) Efektivitas kerja Aparatur Sipil Negara dalam pelayanan publik pada kantor ATR/BPN Provinsi Sumatera Barat saat ini masih belum efektif. Hal ini dikarenakan ada beberapa permasalahan yang terjadi dan belum terselesaikan dengan baik. Hal ini misalnya terjadi ketika seorang ASN divonis karena kesalahan dalam pelayanan HGB dan ASN tidak mendapatkan pendampingan hukum, pemerintah hanya melakukan upaya penyelesaian kasus Hak Guna Bangunan.
\end{abstract}

Kata Kunci: Perlindungan Hukum, Pegawai Negeri

\title{
PENDAHULUAN
}

Peran Aparatur Sipil Negara untuk menyelenggarakan pemerintahan dan pembangunan dalam rangka usaha mencapai tujuan Nasional.Kelancaran penyelenggaraan tugas dan pembangunan nasional sangat tergantung pada kesempurnaan aparatur Negara khususnya Aparatur Sipil Negara. Karena itu, dalam rangka mencapai tujuan pembangunan nasional yakni mewujudkan masyarakat madani yang taat hukum, demokratis, makmur, adil dan bermoral tinggi, diperlukan Pegawai Negeri yang merupakan unsur aparatur negara yang bertugas sebagai abdi masyarakat yang harus menyelenggarakan pelayanan secara adil dan merata kepada masyarakat dengan dillandasi kesetiaan kepada pancasila dan Undang-Undang Dasar Negara Republik Indonesia 1945. ${ }^{1}$

Penegasan dalam pembukaan Undang-undang Dasar Negara Republik Indonesia Tahun 1945 merupakan bagian dari upaya untuk mencapai tujuan nasional, karenanya negara memerlukan sarana prasarana yang mendukung, baik berupa sumber daya manusia maupun sarana dan prasarana. Upaya yang harus dilakukan negara dalam mencapai tujuan nasional yaitu dengan peningkatan kualitas manusia (masyarakatnya) secara berkelanjutan,

\footnotetext{
${ }^{1}$ Dessler Gary, Manajemen Sumber Daya Manusia. PT. Prenhallindo, Jakarta, 2001, hlm. 329.
} 
berlandasan kemampuan nasional dengan memanfaatkan kemajuan ilmu pengetahuan dan teknolagi serta memperhatikan perkembangan sosial. Dalam pencapaian tujuan tersebut, negara Indonesia harus melaksanakan fungsi pemerintahan dengan memberikan perlindungan hukum bagi rakyatnya dalam bentuk pembinaan, pengayoman dan partisipasi dan komponen terpentingnya adalah pegawai negeri dan masyarakat. Dimana Pegawai Negeri Sipil merupakan aparatur negara yang melaksanakan tugas dan kewajiban negara.

Undang-Undang Nomor 5 Tahun 2014 Tentang Aparatur Sipil Negara dalam penjelasannya menjelaskan bahwa guna mencapai tujuan nasional berdasarkan alinea ke-4 Pembukaan UUD NRI 1945 diperlukan Aparatur Sipil Negara yang profesional, bebas dari intervensi politik, bersih dari praktik korupsi, kolusi, dan nepotisme (KKN), mampu menyelenggarakan pelayanan publik bagi masyarakat dan mampu menjalankan peran sebagai perekat persatuan dan kesatuan bangsa berdasarkan Pancasila dan UUD NRI. Demi tercapainya tujuan nasional tersebut maka negara sangatlah memerlukan sarana prasarana yang mendukung berupa sumber daya manusia dalam hal ini ASN maupun sarana yang berbentuk benda karena negara tidak dapat melakukannya sendiri. ${ }^{2}$

Berdasarkan Pasal 1 angka 3 Undang-Undang Nomor 5 Tahun 2014 yang dimaksud Pegawai Negeri Sipil yang selanjutnya disingkat PNS adalah warga negara Indonesia yang memenuhi syarat tertentu, diangkat sebagai Pegawai ASN secara tetap oleh pejabat pembina kepegawaian untuk menduduki jabatan pemerintahan. PNS memiliki peran penting yakni merupakan alat yang ampuh untuk menyelenggarakan tugas-tugas pembangunan dan pelayanan terhadap masyarakat serta tanggung jawab dalam tercapainya tujuan nasional. PNS sebagai bagian dari aparatur negara dituntut mampu berkiprah dan berperan dalam dinamika pembangunan bangsa, sebagai motor penggerak yang handal dan dinamis. ${ }^{3}$

Di era globalisasi seperti saat ini tentunya pelayanan yang baik menjadi tolak ukur terhadap efektivitas dari kinerja pegawai disuatu kantor. Karena tercapainya tujuan suatu organisasi sangat berbanding lurus dengan kinerja pegawai yang ada di kantor tersebut. Setiap instansi atau kantor tentunya mengharapkan pegawainya mampu melaksanakan tugas secara efektif, efesien, produktif dan profesional. Hal ini ditujukan untuk sumber daya manusia serta memiliki daya saing untuk menghasilkan pelayan masyarakat sesuai dengan keinginan masyarakat.

Dalam proses pelayanan publik ada ciri-ciri dalam mengukur kualitas pelayanan publik antara lain: ${ }^{4}$

1. Ketepatan waktu pelayanan, meliputi waktu tunggu dan proses

2. Akurasi pelayanan, yang meliputi bebas dari kesalahan;

3. Kesopanan dan keramahan dalam memberikan pelayanan;

4. Kemudahan mendapatkan pelayanan, misalnya banyaknya petugas yang melayani dan banyaknya fasilitas pendukung seperti komputer;

\footnotetext{
${ }^{2}$ Rozali Abdullah, Hukum Kepegawaian. Rajawali, Yogyakarta, 1986, hlm. 53

${ }^{3}$ Agus Yudha Hernoko, 'Perceraian di Lingkungan Pegawai Negeri Sipil. Studi Observasi Terhadap Alasan Perceraian dan Penegakan Disiplin di Lingkungan Pemerintah Daerah Tingkat I Jawa Timur'. X Yuridika. Jawa Timur, 1995, hlm. 28

${ }^{4}$ Fandy Tjiptono. Service management Mewujudkan Layanan Prima. Penerbit C. Vandi Ofset Edisi II, Yogyakarta, 2000. Hlm 31
} 
5. Kenyamanan dalam memperoleh pelayanan, berkaitan dengan lokasi, ruang tempat pelayanan, tempat parkir, ketersediaan informasi dan lain-lain;

6. Atribut pendukung pelayanan lainnya seperti ruang tunggu ber-Ac, kebersihan dan lain-lain (Papan Bagan sturktur, Maklumat pelayanan).

Kemudian untuk dapat menilai sejauh mana kualitas pelayanan publik yang diberikan oleh aparatur pemerintah, perlu ada kriteria yang menunjukkan apakah suatu pelayanan publik yang diberikan dapat dikatakan baik atau buruk. Ada 10 (sepuluh) dimensi yang harus diperhatikan dalam melihat tolok ukur kualitas pelayanan publik, yaitu sebagai berikut: ${ }^{5}$

a. Tangible, terdiri atas fasilitas fisik, peralatan, personil dan komunikasi;

b. Realiable, terdiri dari kemampuan unit pelayanan dalam menciptakan pelayanan yang dijanjikan dengan tepat;

c. Responsiveness, kemauan untuk membantu konsumen bertanggung jawab terhadap kualitas pelayanan yang diberikan;

d. Competence, tuntutan yang dimilikinya, pengetahuan dan ketrampilan yang baik oleh aparatur dalam memberikan pelayanan;

e. Courtesy, sikap atau perilaku ramah, bersahabat, tanggap terhadap keinginan konsumen serta mau melakukan kontak atau hubungan pribadi;

f. Credibility, sikap jujur dalam setiap upaya untuk menarik kepercayaan masyarakat;

g. Security, jasa pelayanan yang diberikan harus bebas dari berbagai bahaya dan resiko;

h. Access, terdapat kemudahan untuk mengadakan kontak dan pendekatan;

i. Communication, kemauan pemberi pelayanan untuk mendengarkan suara, keinginan atau aspirasi pelanggan, sekaligus kesediaan untuk selalu menyampaikan informasi baru kepada masyarakat;

j. Understanding the customer, melakukan segala usaha untuk mengetahui kebutuhan pelanggan.

Badan Pertanahan Nasional Provinsi Sumatera Barat sebagai unit kerja perencanaan yang menjalankan tugas, fungsi, kewenangan serta tanggung jawab koordinasi dibidang pertanahan diperlukan kehadiranya untuk menunjang keberhasilan pembangunan daerah. Dengan deskripsi tugas yang begitu penting, maka diperlukan dinas Badan Pertanahan Nasional Provinsi Sumatera Barat dengan dukungan aparatur yang memadai baik dari segi kualitas maupun kuantitasi untuk mendukung pencapaian sasaran dan prioritas pembangunan daerah. Dalam Undang-undang Nomor 25 Tahun 2009 Tentang Pelayanan Publik dalam pasal 11 menyebutkan sebagai berikut: Pelayanan publik adalah kegiatan atau rangkaian kegiatan dalam rangka pemenuhan kebutuhan pelayanan sesuai dengan peraturan perundangundangan bagi setiap warga negara dan penduduk atas barang, jasa, dan/atau pelayanan administratif yang disediakan oleh penyelenggara publik.

Pelayanan publik menjadi fokus persoalan yang perlu memperoleh perhatian dan perlu penyelesaian yang komprehensif. Pada dasarnya setiap manusia membutuhkan pelayanan, bahkan secara ekstrim dapat dikatakan bahwa pelayanan tidak dapat dipisahkan dari kehidupan manusia. Masyarakat setiap waktu menuntut pelayanan publik yang berkualitas dari instansi, meskipun hasil dari tuntutan tersebut sering tidak sesuai dengan harapan.

\footnotetext{
${ }^{5}$ A Parasuraman, valarie A. Zeithmal, Leornard L. Berry. "Delivering Quality Service : Balancing Customer Perception and Expectations" The Free Press. 1990. Hlm 25
} 
Berdasarkan Keputusan Menteri Pemberdayagunaan Aparatur Negara Nomor 63 Tahun 2003 Tentang Pedoman Umum Penyelenggaraan Pelayanan Publik menyebutkan, prosedur pelayanan, persyaratan pelayanan, kemampuan petugas pelayanan, kecepatan pelayanan, keadilan mendapatkan pelayanan, kepastian biaya pelayanan, dan kepastian jadwal pelayanan maka pemerintah memiliki konsekuensi untuk meningkatkan pelayanan dalam sektor pelayanan publik. Pada umumnya, pelayanan publik perlu memperhatikan kebutuhan masyarakat selaku konsumen.

Dalam pelaksanaan tugasnya seorang Pegawai negeri Sipil (PNS) tidak terlepas dari kekurangan dan kelebihan yang dilakukanya, salah satu contoh pelanggaran yang dilakukan oleh Aparatur Sipil Negara Badan Pertanahan Nasional Agam dengan dugaan kasus tindak pidana korupsi dan penyalahgunaan sertifikat rumah toko (Ruko), kios di pasar Lama Lubuk Basung. Pegawai ATR/BPN tersebut telah menyalahgunakan wewenangnya menerbitkan atau memperpanjang hak guna bangunan (HGB) ruko Pasar Lama Lubukbasung semasa masih aktif. Atas perbuatan tersangka, sejak 2009 sampai 2014, biaya sewa ratusan ruko dan kios di Pasar Lama Lubuk basung tidak pernah lagi masuk ke Pendapatan Asli Daerah (PAD) Agam.

Dengan adanya penerapan asas serta kode etik dan kode perilaku ASN" terkait pelanggaran yang telah terjadi di lapangan tidak serta merta membuat PNS yang terlibat pelanggaran tersebut akan langsung mendapatkan sanksi dan dapat dihukum, akan tetapi PNS tersebut mempunyai hak untuk diberikan perlindungan hukum. Hal ini sejalan dengan pasal 3 huruf f Undang-Undang No. 5 Tahun 2014 yang menyatakan bahwa "PNS sebagai profesi berlandaskan pada prinsip jaminan perlindungan hukum dalam melaksanakan tugas". Selanjutnya dalam pasal 126 ayat (3) huruf b Undang-Undang Nomor 54 Tahun 2014 yang mengatakan bahwa "Dalam mencapai tujuan sebagaimana dimaksud pada ayat (2) korps profesi ASN Republik Indonesia memiliki fungsi memberikan perlindungan hukum dan advokasi kepada anggota korps profesi ASN Republik Indonesia terhadap pelanggaran. ${ }^{6}$

Ketika seorang ASN terjebak dalam masalah hukum saat melaksanakan tugas. Negara harusnya hadir untuk membela dengan mempertimbangkan asas praduga tak bersalah. Seorang PNS harus diperlakukan sama di depan hukum. Pemberian bantuan hukum diberikan dalam ruang lingkup permasalahan hukum yang dialami oleh seorang ASN yang membutuhkan bantuan karena keterlibatannya dalam masalah hukum yakni berupa tindakan yang dilakukan oleh penasehat hukum berupa nasehat, pertimbangan, pengertian, dan pengetahuan hukum kepada PNS yang membutuhkan bantuan hukum terhadap permasalahan yang sedang dihadapi. Berdasarkan uraian diatas penulis tertarik mengkajinya dalam bentuk tesis dengan judul" Perlindungan Hukum Bagi Aparatur Sipil Negara Terhadap Pelayanan Publik Pada Kantor Wilayah ATR/BPN Provinsi Sumatera Barat"

\section{METODE PENELITIAN}

Metode yang digunakan adalah hanya pendekatan yuridis normatif dengan hanya menggunakan data sekunder yang diperoleh melalui studi kepustakaan. Data tersebut kemudian di analisis secara kualitatif dan disajikan dalam bentuk deskriptif kualitatif

\footnotetext{
${ }^{6}$ http://klikpositif.com/baca/6210/terkait-kasus-korupsi-pasar-lama--kejari-lubukbasung-tahan-dua-mantanpejabat-bpn-agam, (diakses tanggal 10 Januari 2020, Pukul 20:00 wib)
} 


\section{PEMBAHASAN}

\section{A. Perlindungan Hukum Bagi Aparatur Sipil Negara dalam memberikan pelayanan kepada publik di kantor ATR/BPN Provinsi Sumatera Barat}

Manajemen sumber daya aparatur merupakan salah satu bagian terpenting dalam suatu pemerintahan. Dalam suatu pemerintahan yang baik adalah pemerintahan yang mampu memberikan pelayanan terbaik untuk masyarakat baik dari segi kecepatan maupun ketepatan dalam pelayanan publik dan ketepatan sasaran bagi masyarakat yang membutuhkan. Sehingga kebutuhan masyarakat terhadap kepentingan pribadi dan umum dapat tercapai dengan maksimal. Pemerintah telah melakukan upaya untuk meningkatkan kinerja sumber daya aparatur negara, misalnya setiap tahun diadakan proses rekrutmen calon pegawai negeri sipil (CPNS). Hal itu merupakan tindakan nyata pemerintah untuk meningkatkan kinerja sumber daya aparatur negara karena melalui proses rekrutmen tersebut diharapkan dapat mencetak sumber daya aparatur yang berkualitas dan mampu bersaing dalam memberikan pelayanan kepada publik secara maksimal.

Upaya pembenahan birokrasi bukan upaya baru yang dilakukan pada masa reformasi, tetapi menjadi program pemerintah sejak masa Orde Baru. Pada dekade pertama pemerintahan Orde Baru, pembenahan birokrasi ditujukan untuk meningkatkan efisiensi dan efektivitas birokrasi sehingga mendukung stabilitas nasional. Konsepsi ini sejalan dengan ideologi pembangunan dan modernisasi yang dianut oleh pemerintah Orde Baru, yang mensyaratkan stabilitas politik sebagai prasyarat bagi pertumbuhan ekonomi. Birokrasi dan teknokrasi berperan sebagai aktor dominan dalam mengarahkan pembangunan.

Aparatur Sipil Negara (ASN) mempunyai kedudukan dan peranan yang penting serta menentukan dalam penyelenggaraan Negara/Pemerintahan. Kelancaran pelaksanaan pembangunan nasional pada pokoknya tergantung semangat, tekad, sikap mental, dan kedisiplinan aparatur negara. Mengingat pentingnya peranan Aparatur Sipil Negara (ASN) dalam pembangunan nasional maka perlu diberikan perlindungan, pemeliharaan, serta peningkatan kesejahteraan sehingga pada gilirannya akan dapat meningkatkan produktivitas kerja.

Undang-Undang Nomor 5 Tahun 2014 tentang Aparatur Sipil Negara (disingkat dengan UU ASN) lahir dalam rangka pelaksanaan cita-cita bangsa dan mewujudkan tujuan negara sebagaimana tercantum dalam Pembukaan Undang-Undang Dasar Negara Republik Indonesia Tahun 1945, perlu dibangun aparatur sipil negara yang memiliki integritas, profesional, netral dan bebas dari intervensi politik, bersih dari praktik korupsi, kolusi, dan nepotisme, serta mampu menyelenggarakan pelayanan publik bagi masyarakat dan mampu menjalankan peran sebagai unsur perekat persatuan dan kesatuan bangsa berdasarkan Pancasila dan Undang-Undang Dasar Negara Republik Indonesia Tahun 1945. Undang-Undang ASN hadir untuk menggantikan Undang-Undang Nomor 8 Tahun 1974 tentang Pokok-Pokok Kepegawaian sebagaimana telah diubah dengan Undang-Undang Nomor 43 Tahun 1999 tentang Perubahan atas Undang-Undang Nomor 8 Tahun 1974 tentang Pokok-Pokok Kepegawaian karena sudah tidak sesuai dengan tuntutan nasional dan tantangan global. Pelaksanaan manajemen aparatur sipil negara harus berdasarkan pada perbandingan antara kompetensi dan kualifikasi yang diperlukan oleh jabatan dengan kompetensi dan kualifikasi yang dimiliki calon dalam rekrutmen, 
pengangkatan, penempatan, dan promosi pada jabatan sejalan dengan tata kelola pemerintahan yang baik dan untuk mewujudkan aparatur sipil negara sebagai bagian dari reformasi birokrasi, perlu ditetapkan aparatur sipil negara sebagai profesi yang memiliki kewajiban mengelola dan mengembangkan dirinya dan wajib mempertanggungjawabkan kinerjanya.

Dalam Pasal 10 dijelaskan bahwa Pegawai ASN berfungsi sebagai: pelaksana kebijakan publik, pelayan publik serta perekat dan pemersatu bangsa. Sedangkan tugas Pegawai ASN menurut Pasal 11 adalah:

a. melaksanakan kebijakan publik yang dibuat oleh Pejabat Pembina Kepegawaian sesuai dengan ketentuan peraturan perundang-undangan;

b. memberikan pelayanan publik yang profesional dan berkualitas; dan

c. mempererat persatuan dan kesatuan Negara Kesatuan Republik Indonesia.

Selanjutnya di dalam Pasal 12 dijelaskan Pegawai ASN berperan sebagai perencana, pelaksana dan pengawas penyelenggaraan tugas umum pemerintahan dan pembangunan nasional melalui pelaksanaan kebijakan dan pelayanan publik yang profesional, bebas dari intervensi politik, serta bersih dari praktik korupsi, kolusi, dan nepotisme.

Seiring dengan perkembangan peraturan perundang-undangan terkait kepegawaian, peraturan perundang-undangan terkait otonomi daerah juga mengalami perubahan. Undang-undang Nomor 22 Tahun 1999 telah diubah dengan Undang-undang Nomor 32 tahun 2004 tentang Pemerintahan Daerah, dan sekarang telah diganti dengan Undang-undang Nomor 23 Tahun 2014. Otonomi Daerah adalah hak, wewenang dan kewajiban daerah otonom untuk mengatur dan mengurus sendiri Urusan Pemerintahan dan kepentingan masyarakat setempat dalam sistem Negara Kesatuan Republik Indonesia. Penyelenggaraan Pemerintahan Daerah diarahkan untuk mempercepat terwujudnya kesejahteraan masyarakat melalui peningkatan pelayanan, pemberdayaan, dan peran serta masyarakat, serta peningkatan daya saing daerah dengan memperhatikan prinsip demokrasi, pemerataan, keadilan, dan kekhasan suatu daerah dalam sistem Negara Kesatuan Republik Indonesia. Pemerintah Daerah adalah Kepala Daerah sebagai unsur penyelenggara Pemerintahan Daerah yang memimpin pelaksanaan urusan pemerintahan yang menjadi kewenangan daerah otonom. Kepala Daerah di dalam UU ASN berfungsi sebagai Pejabat Pembina Kepegawaian Daerah. Pejabat Pembina Kepegawaian adalah pejabat yang mempunyai kewenangan menetapkan pengangkatan, pemindahan, dan pemberhentian Pegawai ASN dan pembinaan Manajemen ASN di instansi pemerintah sesuai dengan ketentuan peraturan perundang-undangan.

Pada Ketentuan Penutup Undang-Undang ASN dinyatakan bahwa pada saat Undang-undang ini berlaku, maka Undang-Undang Nomor 8 Tahun 1974 tentang PokokPokok Kepegawaian dicabut dan dinyatakan tidak berlaku1. Namun pada pasal lainnya juga dinyatakan bahwa pada saat Undang-Undang ini mulai berlaku, semua peraturan perundang-undangan yang merupakan peraturan pelaksanaan dari Undang-Undang Nomor 8 Tahun 1974 dinyatakan masih tetap berlaku sepanjang tidak bertentangan dan belum diganti berdasarkan Undang Undang ini, akan tetapi selain Undang-Undang tersebut, juga terdapat Undang-Undang Nomor 5 Tahun 2014 tentang Aparatur Sipil Negara. 
Sejak lahirnya Undang-Undang Nomor 5 Tahun 2014 tentang Aparatur Sipil Negara semakin memperkokoh adanya kewajiban negara untuk memberikan perlindungan, pendampingan dan bantuan hukum, dimana perlindungan dan bantuan hukum diberikan kepada ASN yang terjerat hukum karena pelaksanaan tugasnya. Berdasarkan Pasal 21 Huruf d dan Pasal 22 Huruf c, UU Nomor 5 Tahun 2014 , "ASN berhak memperoleh perlindungan“, serta Pasal 92 Ayat (1) Huruf d dan Pasal 106 Ayat (1) Huruf e "Pemerintah wajib memberikan perlindungan berupa: bantuan hukum". Ayat (3) "Bantuan hukum sebagaimana dimaksud pada Pasal 106 Ayat (1) Huruf e berupa bantuan hukum dalam perkara yang dihadapi di pengadilan terkait pelaksanaan tugasnya". Namun bantuan hukum tidak diberikan kepada ASN yang terlibat masalah hukum / tindak pidana khusus seperti korupsi, narkoba dan terorisme.

ASN tidak berhak mendapatkan bantuan hukum jika ASN tersebut sudah mendapatkan surat keputusan yang menjelaskan bahwa yang bersangkutan terbukti melakukan kesalahan dari Pejabat Pembina Kepegawaian (PPK) dengan jenis hukuman disiplin berat berupa pemberhentian dengan hormat tidak atas permintaan sendiri sebagai PNS dan pemberhentian tidak dengan hormat sebagai PNS. Hal ini disebabkan karena status yang bersangkutan sudah bukan PNS berdasarkan keputusan PPK dan tidak dimungkinkan bagi unit kerja yang menangani bantuan hukum menentang keputusan pimpinan/dinas tersebut.

\section{B. Efektifitas Kerja Aparatur sipil negara dalam pelayanan publik di kantor ATR/BPN Provinsi Sumatera Barat.}

Kelancaran penyelenggaraa tugas pemerintahan dan pembangunan nasional sangat tergantung pada kesempurnaan aparatur Sipil Negara (ASN), sebagaimana yang dijelaskan dalam Undang-Undang (UU) Nomor 5 Tahun 2014 tentang Aparatur Sipil Negara. ASN di kantor ATR/BPN adalah para pegawai yang berkedudukan sebagai unsur aparatur negara yang bertugas untuk memberikan pelayanan kepada masyarakat (termasuk pelayanan di bidang administrasi) dengan "lima S (senyum, salam, sapa, semangat, dan sepenuh hati). Dalam pelayanan administrasi tersebut, dikenal dengan pelayanan sepenuh hati, yakni pelayanan yang berasal dari dalam sanubari diri para ASN. Sanubari merupakan tempat bersemayamnya emosi, watak, keyakinan, nilai, sudut pandang dan perasaan para ASN. Pelayanan administrasi sepenuh hati ASN dilaku kan berdasarkan pada pertimbangan logis (pikiran) dan perasaan.Untuk itu, dalam pelayanan administrasi sepenuh hati di Kantor ATR/BPN kota Padang, yaitu bagaimana ASN memandang diri sendiri, memandang orang lain dan memandang pekerjaan. Dalam memandang diri sendiri, ASN memiliki penuh kepercayaan diri terhadap dirinya sendiri. ASN memiliki kemampuan berhubungan dengan orang lain. Suka menyenangkan hati pelanggan dan tidak memandang dirinya rendah karena pekerjaan. ASN tidak hanya ramah dan profesional, tetapi juga mampu menjalin hubungan emosional dengan setiap pelanggan yang datang. ASN bangga terhadap dirinya, karena selama ini belum pernah merugikan orang lain, bahkan terus berusaha menambah makna terhadap pekerjaannya. Ditegaskan, bahwa pelayanan administrasi 
kepada masyarakat di sini merupakan rangkaian kegiatan administrasi dalam rangka pemenuhan kebutuhan pelayanan sesuai peraturan perundang-undangan. ${ }^{7}$

Bentuk pelayanan tersebut di antaranya adalah pelayanan administratif sebagaimana dikemukakan di atas, yaitu pelayanan yang menghasilkan berbagai bentuk dokumen resmi yang dibutuhkan oleh publik. ${ }^{8}$ Ada pun pelayanan administrasi tersebut di antaranya adalah pelayanan di bidang pertanahan berupa hak guna bangunanyang berada diatas hak pengelolaan.

Kebutuhan akan tanah dalam rangka meningkatkan kegiatan usaha semakin meningkat, maka diperlukan suatu hak yang memberikan kewenangan besar kepada pemegang hak untuk merencanakan peruntukan dan penggunaan tanah yang bersangkutan guna keperluan usahanya. Hak Pengelolaan menurut Pasal 1 Peraturan Menteri Dalam Negeri Nomor 1 Tahun 1977 tentang Tata Cara Permohonan Dan Penyelesaian Pemberian Hak Atas Bagian-Bagian Tanah Hak Pengelolaan Serta Pendaftarannya adalah: 1. Hak pengelolaan, yang berisi wewenang untuk : a. Merencanakan peruntukkan dan penggunaan tanah yang bersangkutan; b. Menggunakan tanah tersebut untk keperluan pelaksanaan usahanya; c. Menyerahkan bagian-bagian daripada tanah itu kepada pihak ketiga menurut persyaratan yang ditentukan oleh perusahaan pemegang hak tersebut, yang meliputi segi-segi peruntukkan, penggunaan, jangka waktu, dan keuangannya, dengan ketentuan bahwa pemberian hak atas tanah kepada pihak ketiga yang bersangkutan dilakukan oleh pejabat-pejabat yang berwenang, sesuai dengan peraturan perundang-undangan yang berlaku. 2. Hak Pengelolaan yang berasal dari pengkonversian Hak penguasaan berdasarkan Peraturan Menteri Agraria nomor 9/1965 tentang Pelaksanaan Konversi Hak Penguasaan Atas Tanah Negara Dan Ketentuan Tentang Kebijaksanaan Selanjutnya yang memberi wewenang sebagaimana tersebut dalam ayat 1 diatas dan yang telah didaftarkan di Kantor Sub Direktorat Agraria setempat serta sudah ada Sertipikatnya. Dalam memberikan ruang yang seluas-luasnya kepada daerah, untuk mengurusi barang-barang yang menjadi kepemilikannya, menurut Undang-undang Nomor 33 tahun 2004 tentang Perimbangan Keuangan antara Pemerintah Pusat dan Pemerintah Daerah barang-barang tersebut dikelola dan dimanfaatkan untuk pemenuhan kebutuhan dan kepentingan masyarakat serta pencapaian kesejahteraan masyarakat. Pengelolaan Barang Milik Daerah yang dimaksud mencakup bumi, ruang angkasa dan kekayaan alam yang terkandung didalamnya. Pengelolaan tanah sebagai Barang Milik Daerah didasarkan pada Undang-undang Pokok Agraria (UUPA). Undang-undang Pokok Agraria ini lahir dari Pasal 33 ayat (3) Undang-undang Dasar 1945, kemudian termanifestasikan dalam Pasal 2 ayat (1) UUPA yang mengandung asas Hak Menguasai Negara. Hak tersebut bukan berarti bahwa Negara sebagai pemilik atas tanah yang ada diwilayah Negara Kesatuan Republik Indonesia, namun negara sebagai organisasi kekuasaan seluruh rakyat pada tingkatan tertinggi.

\footnotetext{
${ }^{7}$ Kadarisman, Manajemen Pengem bangan Sumber Daya Manusia, Depok: PT RajaGrafindo Persada, Depok, 2013, hlm 21

${ }^{8}$ Pasolong, Harbani, Teori Administrasi Publik. Bandung: CV Alfabeta, Bandung, 2014,hlm. 41-60
} 


\section{PENUTUP}

\section{A. Kesimpulan}

Perlindungan hukum bagi Aparatur Sipil Negara dalam memberikan pelayanan kepada publik di kantor ATR/BPN Provinsi Sumatera Barat pada kenyataannya masih belum maksimal. Hal ini dikarenakan pembenahan birokrasi yang ditujukan untuk meningkatkan efisiensi dan efektivitas birokrasi masih belum terlaksana dengan baik dan kewajiban pemerintah memberikan perlindungan belum terwujud.

Efektifitas kerja Aparatur Sipil Negara dalam pelayanan publik di kantor ATR/BPN Provinsi Sumatera Barat masih dirasakan belum efektif saat ini. Hal ini dikarenakan ada beberapa masalah yang terjadi dan belum terselasaikan dengan baik. Terlebih dalam hal ini terjadi ketika ada seorang ASN yang di pidanakan karena kesalahan dalam pelayanan Hak Pengelolaan HGB dan ASN tersebut tidak mendapatkan bantuan hukum, pemerintah hanya melakukan upaya untuk penyelesaian kasus Hak Guna Bangunan tersebut.

\section{B. Saran}

Perlindungan hukum bagi Aparatur Sipil Negara diberikan dalam ruang lingkup permasalahan hukum yang dialami oleh seorang ASN yang membutuhkan bantuan harus ditingkatkan dan perlu dibentuk suatu lembaga yang berkompeten dan bersifat profesional untuk membantu dalam memberikan perlindungan terhadap ASN sesuai peraturan yang berlaku.

Dalam memberikan efektifitas kerja diperlukanpenerapan asas serta kode etik dan kode perilaku ASN" terkait pelanggaran yang telah terjadi di lapangan supaya ASN yang terlibat pelanggaran tersebut tidak langsung diberikan sanksi dan mendapatkan hukuman.

\section{REFERENSI}

Agus Yudha Hernoko, 'Perceraian di Lingkungan Pegawai Negeri Sipil. Studi Observasi Terhadap Alasan Perceraian dan Penegakan Disiplin di Lingkungan Pemerintah Daerah Tingkat I Jawa Timur'. X Yuridika. Jawa Timur, 1995.

A Parasuraman, valarie A. Zeithmal, Leornard L. Berry. "Delivering Quality Service : Balancing Customer Perception and Expectations" The Free Press. 1990.

Dessler Gary, Manajemen Sumber Daya Manusia. PT. Prenhallindo, Jakarta, 2001

Fandy Tjiptono. Service management Mewujudkan Layanan Prima. Penerbit C. Vandi Ofset Edisi II, Yogyakarta, 2000.

Rozali Abdullah, Hukum Kepegawaian. Rajawali, Yogyakarta, 1986.

Kadarisman, Manajemen Pengem bangan Sumber Daya Manusia, Depok: PT Raja Grafindo Persada, Depok, 2013.

Pasolong, Harbani, Teori Administrasi Publik. Bandung: CV Alfabeta, Bandung, 2014.

Undang-Undang Dasar Negara Republik Indonesia Tahun 1945.

Undang-undang Nomor 43 Tahun 1999 tentang Pokok-Pokok Kepegawaian. 
Undang-undang Dasar Negara Republik Indonesia Tahun 1945.

Undang-Undang Nomor 5 Tahun 2014 Tentang Aparatur Sipil Negara (Lembaran Negara Republik Indonesia Tahun 2014 Nomor 6, Tambahan Lembaran Negara Republik Indonesia Nomor 5494).

Peraturan pemerintah Nomor 53 Tahun 2010 tentang Disiplin Pegawai Negeri Sipil 